\title{
EDUCATIONAL CHANGE AND INNOVATIVE TEACHING PRACTICE: A STUDY OF THE IMPACT OF REFORMS ON THE WORK OF LECTURERS IN VOCATIONAL EDUCATION AND TRAINING IN ENGLAND AND GERMANY
}

\author{
HUBERT ERTL ${ }^{1}$, H.-HUGO KREMER ${ }^{2}$ \\ ${ }^{1}$ University of Oxford, ${ }^{2}$ University of Paderborn
}

\begin{abstract}
This paper focuses on the connection between system-wide reform in vocational education and training and the implementation of these reforms in learning and teaching processes. The study that is the subject of this paper conducted interviews with teachers in school-based vocational education in England and Germany. These interviews generated data on how teachers perceive reforms and in which ways they adapt their teaching as a result of reforms. This paper concentrates on the question in how far the interpretation of reforms by teachers leads to innovative processes at classroom level. The comparative design of the study aimed at identifying differences in innovative practice of teachers in Germany and England. It is concluded that the comparatively stable situation that German teachers find themselves in allow them to engage more actively in, and reflect more freely on, innovative practices than is possible for teachers in England. In contrast, innovative activities of teachers in England are often focused on the management of new teaching contents and the preparation for the teaching of a constantly changing portfolio of qualifications.
\end{abstract}

Key words: vocational education, vocational training, innovation, school-based VET, VET reform, innovation competence

\section{Introduction}

Reforms in vocational education and training (VET) are a wide-spread and ongoing phenomenon observable in most countries world-wide (Green et al., 2007; Brown et al., 2001). In the European context, reforms in VET at the European Union level seem to be inextricably linked to rationales and aims connected to the economic and monetary union (EACA, 2010). However, the Lisbon agenda links the aims of VET reform within the European Union to the wider challenges of competitiveness and the knowledge economy in a global context (Ertl, 2006). Reform at national level has attempted to affect change in the way vocational learning is organised and conducted in most European countries (Maastricht Consortium, 2004; Green et al., 1999). 
The dynamics of change are considered the only constant feature of information and technology driven societies. VET systems are directly affected by these dynamics and policy-makers in most European countries have reacted with distinct and often prolonged reform agendas. In the UK, for instance, the Foster Report has set the tone for the expected impact of reforms: '(...) a comprehensive set of reforms across the whole of the FE (Further Education) system (...) will provide the basis for a progressive enhancement in FE' (Foster Report, 2005, p. 8). The envisaged improvements of VET as a result of reforms of the framework for training have been for some time a topic in the academic discourse in a number of countries (cf. Green et al., 1999). This is to a certain degree also true for the impact of reforms on the work of teachers and lecturers in the system. For the German context, for instance, Dubs observed that the preparedness of teaching staff to initiate innovation has significantly reduced ("not yet again something new to deal with") (Dubs, 2003).

Against this background, this paper reports on two linked, small-scale projects that investigated the connections between VET reform and the processes of teaching and learning in VET. In particular, the question whether educational reform leads to innovation at classroom level needs to be addressed. Therefore, the main focus of this paper is on the ways in which curricular changes in college-based VET in Germany and England result in innovative teaching and learning processes. The findings were used for conceptualising a follow-up project which is outlined at the end of this paper.

\section{Project 1: An Exploratory Study of Educational Change and Innovation in College-Based VET}

This exploratory study was conducted in Germany and aimed at developing an understanding of the impact of educational change on the work of lecturers at vocational colleges. More precisely, the project attempted to establish the link between VET reform and innovation in college-based learning environments, i.e. whether Teachers and lecturers working in these environments regarded developing innovative practice as part of their professional identity and how 'innovative competence' can be achieved. The study had two main research foci (see Figure 1), (1) a structured review of the relevant literature and (2) a series of interviews with experts in the field and lecturers. Research questions included the following:

- How does educational reform affect the work of lecturers?

- What constitutes innovative activity of lecturers at vocational colleges?

- What role plays innovation in the day-to-day work of lecturers?

- What knowledge, abilities, skills and expertise are necessary for innovative competence?

- What is the connection there between innovative competence and lecturers' professionalism?

- How can 'innovative competence' be developed? 
The results of the two research foci were analysed to achieve a clearer view of the concept of 'innovative competence' of lecturers at vocational colleges in Germany. However, the study also identified a number of gaps in the research. One of these gaps, the lack of relevant comparisons of innovation in college-based VET with other countries, lead to the conception of a similar study in England (see Project 2, down below).

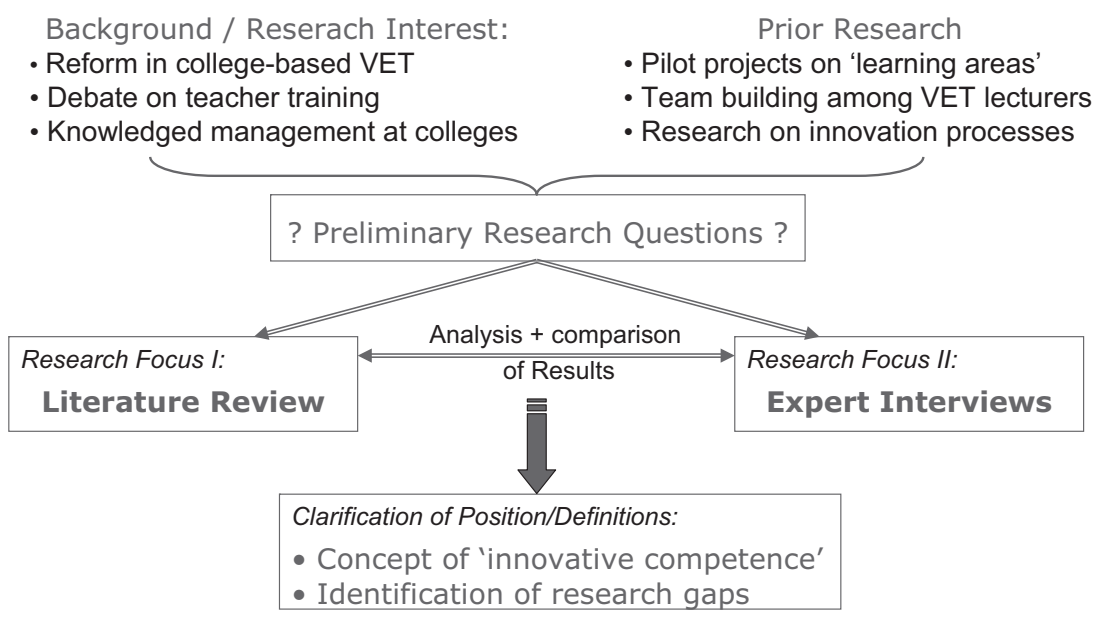

Figure 1. Research design

\section{Research focus 1: literature review}

The literature review was conducted through a structured search of relevant databases and online sources. In addition, ten years of three major academic journals in VET were hand-searched. ${ }^{1}$ It became clear that there have been a number of investigations of particular areas of innovation in education, such as innovation and IT, and the implementation of new curricula. However, there are only few studies that look at the meaning of innovation in colleges in more general or conceptual terms. There were also a number of projects looking at the impact of college leadership on change processes in primary and secondary schools in general, but only a few studies focused on VET contexts (Ertl \& Kremer, 2005a). A further area that has been covered is that of the innovation potential of pilot projects and problems related to the transfer of the findings derived from pilot projects to the wider context. Most of these studies focused on the introduction of IT at schools and colleges. Overall, most of the research on innovation in schools and colleges discussed in the German literature was conducted in the UK or in the USA, relevant research in the German context is rare in comparison. Also, it

1 This search included Zeitschrift für Berufs- und Wirtschaftspädagogik, Zeitschrift Berufsbildung in Wissenschaft und Praxis, Zeitschrift Wirtschaft und Erziehung. 
became clear from the literature review that the research findings have not made a substantial impact on school and college practice. This is particularly the case for research on innovation in other fields than education. For a detailed report on the methodology and findings of the literature review, including some findings from the'non-educational' literature, see Ertl \& Kremer (2005b).

\section{Research focus 2: interviews}

On the basis of the literature review and previous work undertaken in this area, questions for a series of semi-structured interviews were developed. The interviews comprised seven interviewees, including lecturers at vocational colleges, experts from VET research institutes and lecturers involved in teacher training. The interviews focused on the questions in three main areas:

- the perception of innovation by lecturers (lecturers and innovation),

- the connection between innovative practice and lecturers' competence (competence and innovation),

- the pre-conditions for innovative practice at colleges (supporting and hindering factors of innovation).

For analysing the data a hermeneutically-oriented concept developed by Lamnek (1995) was used as a starting point. The concept uses several rounds of analysing interview transcripts and tapes to identify main themes, topics and open questions. After developing an initial understanding of themes, topics and open questions for each interview, clarifications and conceptualisations are sought by comparing concentrated versions of different interviews and identifying similarities and differences between interviews. Lamnek's analytical concept was developed further by systematically making use of the research team members' different perspectives of the interviews. This was achieved by analysing and comparing concentrated transcripts of the interviews independently before jointly discussing differences and similarities between the different interviews. The resulting findings are summarized here according to the three thematic areas stated above:

\section{Lecturers and innovation}

Innovation was perceived by the interviewees as an important element in the work of lecturers at vocational colleges. This general statement is supported by the opinion that most lecturers are motivated to learn new things and to employ them fruitfully in their teaching. They are generally happy to contribute to pilot projects, experiments and other innovative activities. The improvement of teaching processes is seen as a 'continuous and central task of lecturers.' However, if probed further, the interviewed lecturers made it clear that this positive stance mainly covers subject knowledge, for which 'keeping up-to-date' is regarded as essential. Rethinking teaching methods, ways of providing students with advice and

2 Direct quotes in this and the following sections are taken from the expert interviews. 
improving teamwork between lecturers is not at the forefront of lecturers' agendas. Therefore, it can be concluded that innovation is a relevant topic for lecturers, and an issue that has a strong impact on their day-to-day work but only in certain areas of practice.

\section{Innovation and competence}

In the interviews a variety of attitudes and skills were pointed out as being important for teachers' abilities to deal with and to initiate innovation. These included openness, willingness to change, reflection, communication, teamwork and the ability to work in projects. The concept of 'innovative competence' was mentioned by several interviewees who stressed that this competence requires a number of other elements such as communicative competence, learning to learn competence and social competence. Therefore, innovative competence was regarded as a complex 'meta-competence', incorporating other competences. Some interviewees developed a complex map of constituent elements of innovation competence and the connections between these elements. However, the interviewed lecturers stressed that up-to-date knowledge about the subject is at the heart of innovative competence.

\section{Pre-conditions for innovation}

The results in this area of investigation show, inter alia, a strong reluctance of teachers regarding the implementation of external reform initiatives, but also positive attitudes and a high degree of engagement towards reform when it leaves sufficient freedom to determine the direction the reform takes at their college. In this latter case, teachers become the driving force of the development of innovative teaching practices. On the other hand, 'bureaucratic, hierarchical structures', 'rigid organisational patters at colleges', 'top-down reforms', and 'lack of time' were mentioned as hindering factors of innovation. One interviewee encapsulated the ever-increasing pace of change and reform in the phrase 'innovation avalanche' which has a detrimental effect on lecturers' motivation and can even lead to 'resistance to innovation'. In contrast, 'external impulses' (pilot projects, co-operation with training companies, etc.), 'reduction of the number of teaching hours', 'feedback and advice structures', and 'communication tools' were mentioned as factors supporting innovative practice. Overall, the role of college leadership in initiating, supporting and sustaining innovative practice was stressed. Co-operation between teachers seems to be a prerequisite for implementing educational reform. This teamwork between teachers was described as 'in need of improvement' by most interviewees. Therefore, further research has to focus on the behaviour of groups of teachers.

In summary, the findings from the German study show that innovation at vocational colleges is regarded as an important topic, but is actively taken on by lecturers mainly in the areas of subject knowledge and improving teaching 
practice. Organisational and teaching issues, which are important areas of reform in VET at the moment, are not at the forefront of lecturers' agendas. In a triangle constructed by the dimensions of subject knowledge, organisational set-up and teaching concept, the reception of innovations by lecturers at German vocational colleges seems to be firmly located in the corner of subject knowledge. In other words the political reform agenda is interpreted mainly as having an impact on the way lecturers deal with their knowledge about their subject area. This constitutes a tension with educational reforms at the macro level, whose implementation requires far-reaching changes in the organisational structure of colleges and in the concepts of instructions applied by lecturers (sees Figure 2).

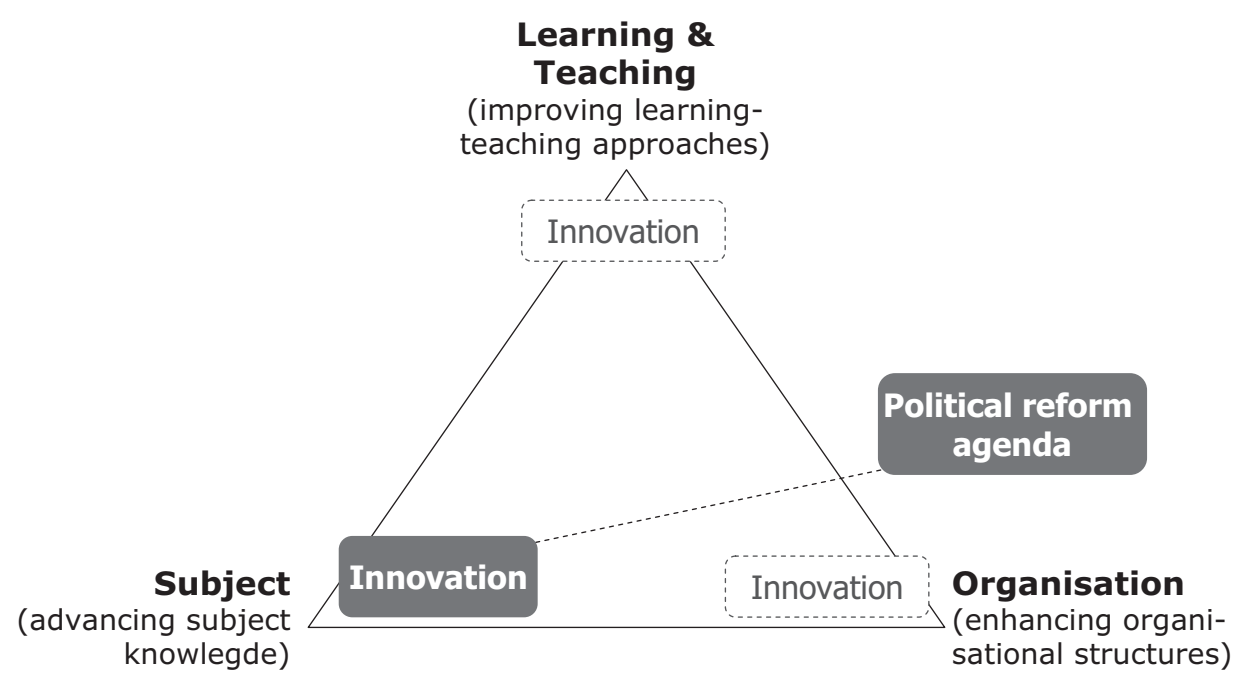

Figure 2. Dimensions of reform and innovation at German vocational colleges

\section{Project 2: Innovation at College-Based Training in a Comparative Perspective}

\section{Rationale and Questions}

The ultimate aim of this research is to develop a better understanding of the implementation of reform processes in college-based VET contexts and to suggest ways in which innovative processes at colleges can be initiated. The underlying assumption is that educational reforms are either implemented in or redefined by pedagogical practice. In the former case, reforms ultimately change the context in which teaching and learning takes place. In the latter case, reforms are revised and the change takes place at the level at which reforms were conceived.

The exploratory study in the German context outlined here was designed around the concept of innovative competence of teachers at vocational colleges. 
On the basis of the experiences in and findings of this study, a further project was developed that looked at similar issues in the English context. The aim of this project was to produce comparable data in another national context in order to determine in how far the findings in Germany are determined by the particularities of VET in Germany and in how far innovative processes in college-based VET contexts are generic and can be found in a similar way in a different system (see Figure 3).

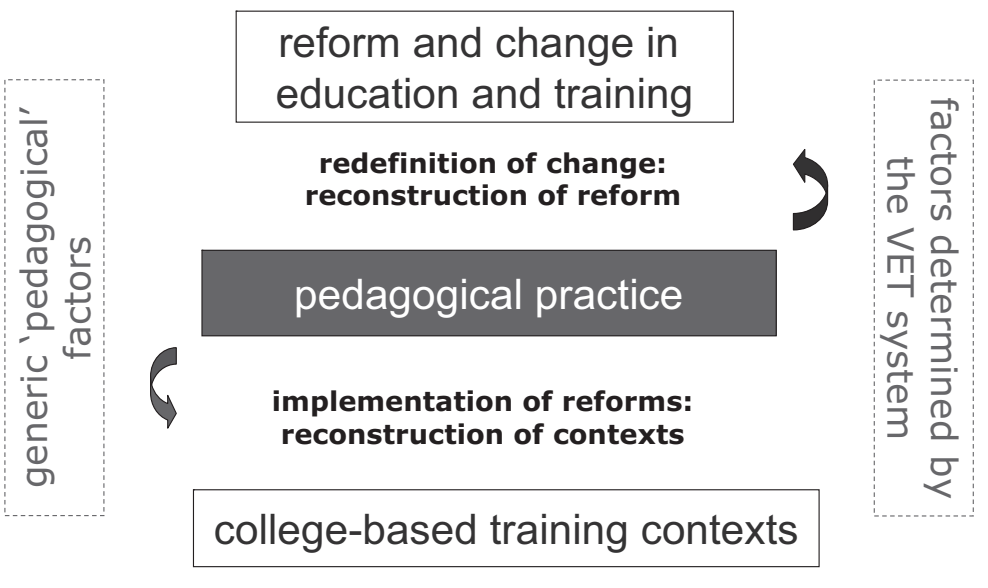

Figure 3. Innovation and reform in VET

An important assumption for the comparative project was that innovative processes are subject to changes at different levels connected to the work at colleges. For instance, at the political level, decisions on the introduction of new qualifications and curricula are made. Key players at this level are the Department for Innovation, Universities and Skills (DIUS), the Department for Children, Schools and Families (DCSF), and the Qualification and Curriculum Authority (QCA) in England and the Standing Conference of Ministers of Culture and Education (Kultusministerkonferenz, KMK) which regulates the college-based part of the dual system of training in Germany. At the instructional level, new teaching and learning arrangements are developed, used and tested by teachers and lecturers on the basis of new qualifications and curricula.

Between the political and the instructional levels, an organisational level can be identified at which the results of political negotiations and prescriptions are transferred to the level of the educational institution; for the project this means vocational colleges in Germany and FE Colleges in England. At this level, organisational preconditions for the development of instructional designs are determined, for instance the resources (time, material, staff, etc.) available for implementing new qualifications and curricula into actual teaching and learning processes. It is important to note that decisions made at one level have an influence on the work at the other two levels and that successful innovation processes usually occur when there are negations across the levels.

The English part of our research aimed to investigate how the wide-ranging 
reforms in the FE sector influence the work of Colleges and teaching personnel. From an institutional perspective, it examined how far the administrative and leadership structures of Colleges are prepared to embrace changes and in how far these structures result in a reactive or proactive stance regarding educational innovation. From a personnel perspective, the lecturers' attitudes towards change were investigated. Their perceptions of current curricula and qualifications reforms were examined as well as the connections between reforms and their translation into educational innovation.

From 2002 onwards, the Department of Education and Skills put increased emphasis on the reform of FE provisions in England. This can be regarded as the continuation of a long line of attempts of structural and organisational reform in the FE sector in recent decades (Lucas, 2004). Nevertheless, the far-reaching aims of the report entitled Success for All - Reforming Further Education and Training and the accompanying consultation process signalled an ongoing reform agenda for the years to come. The suggestions in the 2005 White Paper concerning the introduction of Diploma for 14-19 education and training as a new type of qualification has given the reform process a further impetus and to a certain extent a new direction. The Leitch Review (2006) and the subsequent White Paper Further Education: Raising Skills, Improving Life Chances (DfES, 2006) predicted a rapidly rising demand for skills and attributed a key role to FE Colleges in providing opportunities for skill development. In order to achieve the skills aims, a whole host of reforms affecting 14-19 education in general, and the FE sector in particular, was set out at the political level (for an overview see Hayward et al., 2006).

It is in this situation that the question of the viability of reform becomes an issue. The insight that teachers and lecturers are at the heart of reform processes that result in sustainable innovations in school and college contexts has been described in the relevant literature (cf. for instance Fullan, 1998). However, this has not yet been translated into corresponding research programmes in the English FE sector.

The research aimed to compare the ways reforms and educational change at the system level more widely are implemented in vocational college contexts in England and Germany. On the basis of a substantial understanding of how German lecturers perceive and influence institutional and pedagogic innovation, the particularities of English FE Colleges in terms of their capacity to embrace change were investigated. Research questions included the following:

- What are the contexts and agendas of reform in college-based vocational education in England and Germany?

- What are the perceptions of FE lecturers regarding the reform of the FE sector?

- Are reforms being translated into innovative educational practice?

- What are the main supporting and hindering factors in the development of innovative educational practice in both systems?

- What kinds of working environments are necessary for the implementation of new learning forms?

The main tools applied were a systematic literature and documentary analysis, a 
series of interviews with lecturers and management (including heads) of a number of FE Colleges as well as with policy implementers, and a comparative analysis of quantitative and qualitative data derived from both the English and German contexts.

\section{Findings}

Although the investigation in the English context started from a different contextual background and asked slightly different questions, the following sections try to summarise the first findings from the interviews at FE Colleges using the same categories and a framework similar to the one employed for the data analysis in the German context. The findings are presented in comparison with the German results.

\section{Lecturers and innovation}

Faced with the concept of innovation, lecturers at FE Colleges seemed to be more surprised than their German counterparts by the fact that researchers were asking questions regarding innovative practice and also about the fact that research is conducted in this area at all. The FE lecturers stressed the perception of their work as taking place in a competitive environment, a notion that was not expressed in the German context. Competition with other educational institutions is regarded as a driver for change and improvement, developments which the FE lecturers interviewed described as innovation. While lectures stressed that the introduction of new qualifications (replacing GNVQs, for instance), is often the starting point for changes in their work, they do not really discuss the wider political reform agenda affecting the FE sector and their own work. For these changes, co-operation with agencies developing qualifications, awarding bodies and sometimes with industry was regarded important. Within the college, change is instituted in co-operation of lecturers with their programme managers.

Reflections regarding the content of new qualifications offered at the college were central. Therefore, there seemed to be a focus on subject knowledge in dealing with changes and reforms on the part of the lecturers - a finding that is in line with the results of the German study. The consequences of new subject knowledge for teaching approaches often become apparent only towards the end of a term or a year and do not seem to represent a primary concern for lecturers.

Overall, lecturers regarded work on initiating and carrying out of innovation as lying 'at the periphery of the working day'.3 They stressed that their teaching and administrative commitments only allow them to take on initiatives you which promise 'immediate benefit'.

Similar to the German context, English lecturers also described their perceptions

3 Direct quotes in this and the following sections are taken from the interviews with FE College lecturers. 
of reforms that merely seem to reinvent previous changes. This usually has an adverse effect on the willingness of particularly more experienced lecturers to engage in change processes ('it does become very wiry, you have been there before').

\section{Innovation and competence}

As in the German interviews, FE lecturers stressed the importance of learning to learn competence as an important element of developing innovative practice in their work. The examination of new qualifications and curricular guidelines requires the competence to engage with new contents and challenges. Therefore, the dynamic environment of changing qualifications in FE is regarded as the main impetus for change. This was put in the context of professional development for which lecturers regarded innovation as a central element. Most lecturers focused on formal training, college-based courses and in-service teacher training when being asked about measures that were suitable for preparing them for innovative practice. 'Innovative competence' as a concept was not used by the interviewed lecturers; when asked about it they mentioned 'presentation skills', 'IT-skills', 'communication' and 'co-operation' as important elements of such a competence. It is important to notice that the comparison in this area is impeded by different notions of competence that dominate the VET discourse in England and Germany (cf. Ertl \& Sloane, 2005).

Lecturers frequently mentioned personal attitudes and characteristics as preconditions for innovation:'hunger for research', sharing knowledge with colleagues, and external collaboration (because it is much more productive). More than their German counterparts, FE lecturers mentioned 'sharing ideas with colleagues from other colleges' as both a pre-condition and valuable means of implementing innovation. It appeared that inter-college co-operation is institutionalised at some colleges via working groups or project collaboration. The experience shows that such co-operation across colleges requires a great deal of co-ordination of the shared work as well as measures to build trust between colleagues from different colleges.

\section{Pre-conditions for innovation}

FE lecturers placed greater emphasis than their German colleagues on the lack of time as the main hindering factor for innovative practice. The increase of teaching hours and increased administrative burdens were mentioned as the main factors that have limited the opportunities and motivation of lecturers to engage in change processes and to try out new things in recent years. Some lecturers mentioned the need for dedicated 'research time' in order take innovative initiatives forward. In contrast to the interviews in Germany, FE lecturers compared their situation with that of lecturers in $\mathrm{HE}$, who - in the eyes of FE lecturers - have more room for innovative activities. 
Hindering factors that played a minor role in the German study were mentioned frequently in the interviews at FE colleges were lack of equipment and suitable rooms, inefficient communication and information processes with qualification developers, and fluctuation of teaching staff. This takes on added significance in view of the fact that 'co-operation with other lecturers and programme managers' featured strongly among supporting factors for innovation in the English interviews.

Interestingly, the role of the college leadership was not mentioned as a factor affecting innovation at colleges by FE lecturers. Rather, there was a sense of isolation from the college leadership: 'As long as you deliver bread and butter you are left undisturbed'. Some of the interviewees did not perceive it as the role of the leadership to positively initiate innovation, instead 'they [college leadership] tend to react more to negative things'. This leads to a situation in which lecturers 'are left to deliver our courses with freedom, which is great', but in which they also feel to be '[...] left on [their] own, without direction'.

The role of college-based courses and professional development measures was assessed as ambivalent. Some lecturers regarded these measures as helpful for innovative activities; others saw them mainly as a means of the leadership to control lecturers. Courses on new IT products and developments in the subject were regarded as most valuable.

In summary it can be argued that FE lecturers mainly emphasised the lack of time as the major factor, preventing them from engaging in innovative work. Other factors were discussed at some length and some interesting contrasts with the German context arose. The most important difference seemed to be the perceived lack of impetus from the college leadership, which was not emphasised as strongly by lecturers in Germany. This can be regarded at least partly as a consequence of different organisational set-ups of colleges in the two countries.

Like their German counterparts, lecturers at English FEColleges viewed innovative practice mainly as impacting on their subject knowledge. Organisational changes and implications for teaching approaches were not discussed to a substantial extent. Using a similar triangle for illustrating the results than in the German context, innovation at FE Colleges is also firmly based in the corner of subject knowledge. However, contrary to the German situation, innovative tasks also take place in the process of planning for teaching units for new qualifications. This dimension of lecturers' activities can be regarded as one aspect of what German lecturers discuss within a wider concept of improving teaching and learning approaches. The narrower view of conceptualising and innovating learning-teaching approaches lecturers at English FE Colleges seem to hold, compared with their German colleagues at vocational colleges, probably represents the single most important difference in the professional identity of the two groups.

Similar to the German context, it can be concluded for FE sector in England that there seems to exist a tension between far-reaching educational reforms at the macro level, whose implementation require substantial changes in the organisational structure of colleges and notions of professionalism held by 
lecturers, and the specific ways in which reforms are interpreted and implemented at college level (sees Figure 4).

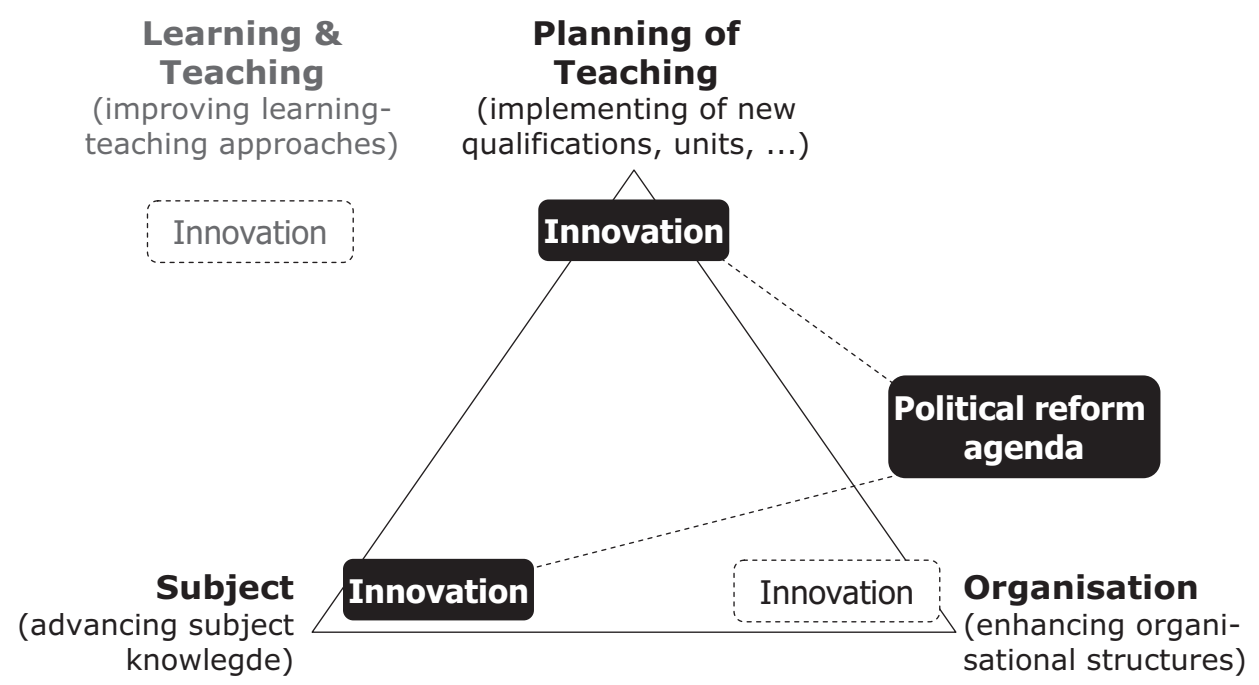

Figure 4. Dimensions of reform and innovation at English FE colleges

\section{Conclusions and Further Research}

The findings and attempts at comparisons between results derived from German and English contexts need to be regarded as tentative and to a certain degree as speculative. Like in qualitative research often the case, limited sample sizes do not allow any generalisations of findings. However, even this smallscale early stage of comparison indicates clearly that the way in which lecturers talk about innovation is very different in the two countries. Whereas the German lecturers are clearly used to discuss innovation and use the concept of innovation competence frequently, English lecturers needed some introduction into this topic. They then emphasise more than their German counterparts the limitations for innovative practice, which are mainly due to time constraints, the pressures of the competitive environment FE Colleges find themselves in, and due to the ever-changing qualification programmes offered by FE Colleges. The more stable situation at German vocational colleges seems to allow lecturers to reflect more freely on innovative practice in general.

It may, therefore, be concluded that innovative activities of FE College lectures are often limited to decisions regarding the management of contents in the teaching of yet another new qualification. In response to the frequent and farreaching changes in short periods of time they are faced with they often react with standardised procedures they develop individually or in teams over time. In contrast, the work of German lecturers is almost entirely unaffected by competitive 
pressures and is guided by a comparatively stable structure of established qualifications. In most cases change takes place at the level of curricula which allows lecturers to make decisions - to some extent - regarding the contents they teach and certainly regarding suitable learning-teaching approaches. It can be argued that German lecturers enjoy a greater degree of pedagogic autonomy in their work, and that overall working conditions allow more space for lecturerinitiated innovation; space that is clearly not always used effectively, particularly in terms innovation of teaching approaches.

The longer duration of teacher training seems to equip German lecturers with a repertoire of 'pedagogical jargon' used to discuss the topic of innovation. However, the influence of more formalised pre-practice teacher training in Germany compared with shorter in-service training in England on innovative competence of lecturers cannot be assessed on the basis of our research because it did not constitute a focus of our investigation.

Despite this limitation, it appears from our interviews that the ways in which the two systems in question develop notions of professionalism of lecturers influence the interpretation of innovation. This is connected with the definitions of roles of lecturers in the two different college systems. Therefore, system-specific factors have a clear influence on how lecturers deal with innovative tasks. Surprisingly similar seems to be that in both systems lecturers tend to focus their attention on subject-specific innovation rather than innovation regarding teaching and learning approaches. In both systems effective ways of developing innovative competence of lecturers still need to be found.

It is hoped that further interviews, accompanied by a more in-depth review of the relevant literature on FE Colleges, will show whether these first impressions can be substantiated. If this is the case, our research would demonstrate the wideranging effects of the respective VET systems, including teacher training structures, on innovative practice in college-based training in England and Germany.

In order to argue this point convincingly, it will also be necessary to improve the conceptual understanding of what represents 'innovation' in college contexts. The lack of a comprehensive and theorised terminological framework was one of the starting points of this research, which was partly confirmed in the literature analysis. More work on concepts developed in other fields of research might be necessary in this respect.

In order to shed some light on these issues, a follow-up project supported by a doctoral grant from the Economic and Social Research Council (ESRC) was initiated in 2010. This project focuses on the impact of educational change on the work of VET lecturers in a comparative perspective. It will build on and broaden the investigation in England and Germany and will extend the comparison to another country, namely Austria. The focus on VET practitioners is based on the assumption that it is teachers and lecturers who are ultimately asked to interpret reforms and to implement change. The project aims to generate a substantially larger data base from interviews with practitioners and classroom level observation. 
It is hoped that the findings from this project will allow us to develop a better understanding of how educational reform is linked to changes in day-to-day pedagogical practice in the area of VET. Due to the different conceptualisations of what is meant by terms such as 'vocational' and 'training' in the three countries of comparison, it is also hoped to develop recommendations for improving the transfer of change intended in political reforms and change that is actually implemented in practice in the area of education more widely.

\section{References}

Brown, P., Green, A., \& Lauder, H. (2001). High Skills: Globalization, Competitiveness and Skill Formation. Oxford: OUP.

Department for Education and Skills (DfES) (2006). Further Education: Raising Skills, Improving Life Chances. London: TSO.

Dubs, R. (2003). Ermüdung und Gleichgültigkeit im schulischen Alltag: Die Verantwortung der Politik und der Wissenschaft. Zeitschrift für Berufs- und Wirtschaftspädagogik, 1, 3-9.

EACEA (2010). (EU Executive Agency Education, Audiovisual \& Culture) Strategic framework for education and training. Retrieved from <http://ec.europa.eu/ education/lifelong-learning-policy/doc28_en.htm>.

Ertl, H. (2006). European Union policies in education and training: the Lisbon agenda as a turning point? Comparative Education, 42(1), 5-27.

Ertl, H. \& Sloane, P. F. E. (Hrsg.) (2005). Kompetenzerwerb und Kompetenzbegriff in der Berufsbildung in internationaler Perspektive. Paderborn: Eusl.

Ertl, H. \& Kremer, H.-H. (Hrsg.) (2005a). Innovationen in schulischen Kontexten: Ansatzpunkte für berufsbegleitende Lernprozesse bei Lehrkräften Paderborn: Eusl.

Ertl, H. \& Kremer, H.-H. (2005b). Der Umgang mit Innovationen an berufsbildenden Schulen: Erste Befunde einer explorativen Studie. Erziehungswissenschaft und Beruf, 4, 451-471.

Foster, A. (2005). Realising the Potential. A review of the future role of further education colleges. London: DfES.

Fullan, M. (1998). The Three Stories of Educational Reform. Kappan Professional Journal. Retrieved from <http://www.pdkintl.org/kappan/kful0004.htm>.

Green, A., Little, A., Kamat, S., Oketch, M. \& Vickers, E. (2007). Education and Development in a Global Era: Strategies for 'Successful Globalisation. DFID.

Green, A., Wolf, A., \& Leney, T. (1999). Convergence and Divergence in European Education and Training Systems. London: Institute of Education.

Hayward, G. et al. (2006). The Nuffield Review of 14-19 Education and Training. Annual Report 2005-06. Oxford: University of Oxford.

Lamnek, S. (1995). Qualitative Sozialforschung. Methoden und Techniken. Weinheim: BeltzPVU.

Leitch Review of Skills (2006). Prosperity for all in the global economy - world class skills. Final Report. Norwich: HMSO. 
Lucas, N. (2004). Teaching in Further Education. New Perspectives for a Changing Context. London: Inst. of Education.

Maastricht Consortium (The Lisbon-to-Copenhagen-to-Maastricht Consortium Partners) (2004). Achieving the Lisbon goal: the contribution of VET. Retrieved from $<$ http://ec.europa.eu/education/policies/2010/studies/maastricht_en.pdf>.

\section{Contact Information}

Dr. Hubert Ertl

Department of Education

University of Oxford

15 Norham Gardens

Oxford, OX2 6PY

hubert.ertl@education.ox.ac.uk

Dr. H.-Hugo Kremer

Universität Paderborn

Department 5: Wirtschaftspädagogik

Warburger Str. 100

33098 Paderborn

hkremer@notes.uni-paderborn.de 